\title{
Online Advertising and Customer Satisfaction of E-Tailing Firms in Nigeria
}

\author{
N. Gladson Nwokah, Doris Ngirika \\ Department of Marketing, Faculty of Management Sciences, Rivers State University, Port Harcourt, Nigeria \\ Email: nwokah.gladson@ust.edu.ng
}

How to cite this paper: Nwokah, N.G. and Ngirika, D. (2018) Online Advertising and Customer Satisfaction of E-Tailing Firms in Nigeria. Intelligent Information Management, 10, 16-41.

https://doi.org/10.4236/iim.2018.101002

Received: November 1, 2017

Accepted: January 2, 2018

Published: January 5, 2018

Copyright $\odot 2018$ by authors and Scientific Research Publishing Inc.

This work is licensed under the Creative

Commons Attribution International

License (CC BY 4.0).

http://creativecommons.org/licenses/by/4.0/

\begin{abstract}
This study examined the Impact of Online Advertising on Customers Satisfaction of E-tailing Firms in Nigeria. A survey research design was adopted. The source of data used in this study was mainly primary data from the issuance of questionnaire and secondary data from the review of relevant literature bothering on both variables which formed the basis for the argument. Out of a total of three hundred and eighty four (384) copies of questionnaire distributed, two hundred and eighty five (285) copies was used for analysis and analyzed using Spearman's Rank Order Correlation Coefficient with the help of Statistical Package for Social Sciences (SPSS). The findings of the study reveal amongst others that there is a positive and strong relationship between online advertising and customers' satisfaction; and online advertising significantly affects customer satisfaction. The study concludes that online advertising influenced satisfaction of the customers to a strong extent. However, online advertising is a key determinant of customer satisfaction as it is considered as a point of interaction between customers and the company from which they buy their products. A heuristic model was proposed to show our contribution to knowledge that the relationship between e-mail marketing and measures of customer satisfaction is very strong and is moderate on all other tested hypotheses. And the study recommends that advertising managers of e-tailing firms must develop and formulate e-mail marketing programs that will satisfy the needs of consumers and advert should be placed on stations and places where consumers can easily identify with them and make a purchase. Suggestions for further studies were outlined.
\end{abstract}

\section{Keywords}

Online, Advertising, Customers, Satisfaction, E-Tailing, Nigeria

\section{Background to the Study}

The internet revolution of the last two decades has changed the ways business 
and personal life is conducted. Globalization is made possible principally due to the growth and development of internet. Most businesses are done electronically to supplement or replace completely the traditional brick and mortar type of businesses. To survive and excel in this fierce competitive world economy, companies have accepted the use of internet globally. Marketing is not left out in this great wind of change that has transformed all sectors of the economy. Internet has changed the rules and marketing practitioners have no choice but to comply. Information and communication technology, as it now called, is now playing a key role in all elements of marketing mix and the new concept acknowledges the importance of communication in their interface between a business and its customers [1].

Internet is not just a new channel of promotion, as it has caused a turning point, a complete shift to a new business model, which results in an inevitable re-conceptualization of the very nature of marketing. The new communication technology has created a new dynamic environment which changed the previous market-oriented, top-to-down and unilateral approach to customer oriented, bottom-to-top and reciprocal process. The internet permits the purchasing of products and services from the comfort of your home or anywhere you have internet access, even in the remotest villages. Goods and services are made available 24/7 and 365 days at the click of a computer mouse or smart phone and other mobile devices. The use of internet for conducting business led to the emergence of such concepts as e-business, e-commerce, e-tailing, etc. Electronic business (e-business) refers to conducting business online while electronic commerce (e-commerce) is part of e-business. E-commerce refers to sharing of business information and conducting of business transactions through the internet or any other telecommunications network [2]. E-tailing or online shopping refers to online shopping where goods and services are sold directly to consumers electronically, which is business to consumer (B2C) [3]. Online shopping has become a popular means of shopping globally and has witnessed a rapid growth in recent times because of its numerous merits for both retailers including consumers such as 24 hours facilities, saving time and cost, convenience, decreased overhead cost [4]. This is especially common in the developed countries where every store has its own website. Online shopping is becoming popular in Nigeria as many people in the cities have realized the benefit of online shopping.

In Nigeria, the use of online advertising is increasing as many firms have entered the online retailing business (e-tailing) [4]. This is to provide the benefit of online shopping. It is not enough to establish e-tailing firms, use various advertising channels, but the ability to satisfy and meet the expectations of customers. Successful customer satisfaction will increase revenue and enhance the company overall performance. Online advertising effectiveness is influenced by such factors as simplicity of advert, attractiveness of advert, location of advert on the website, ease of order placement and prompt delivery, affordable price and quality product, etc. [4]. Effective online advertising inform, convince and retain 
customers. Internet has gain dominance in online shops. But many companies have moved from a product-centric to a customer-centric price. Customer retention directly affects customer satisfaction. Retention is a challenge to customer satisfaction in Nigeria it is of important to study the determinants of customer satisfaction [5]. The key factor in any organization is customer satisfaction, because it determines organization's level of success [5]. According to [6] if a customer is not well taking care of, dissatisfaction will set in which leads to negative word of mouth, customers may switch over to competitors brands and this will lead to reduction in profit, customer turnover, patronage and difficulty in retention. But for a firm to achieve customer satisfaction it should focus on the customers, employee empowerment, process ownership, team building, and partnering with customers and suppliers, improvement of the firm's reputation and image [3].

\section{Theoretical Foundations and Operational Framework}

Instant gratification mathematical theory was originated by Robertz in 1956 [6]. He said that two things are responsible for the successful theory: First, the discount function should be on the difference between the current time and the future time at which discounted reward is consumed. Second, the discount function should not be exponential. He went further to state that empirical discount rate reduces with time horizon. Today's generation has Nicknamed "Microwave generation" because they are used to getting things so fast. Because of internet evolution and technology there is no little to no patience in people any longer. Instant gratification theory saw the fast place environment in which we live that requires instant action and how things happen at once and quickly. By implication online advertising has impact on consumers as that the use of internet to advertise makes it faster, efficient and effective [5].

Figure 1 proposes that online advertising influences customers' satisfaction. It

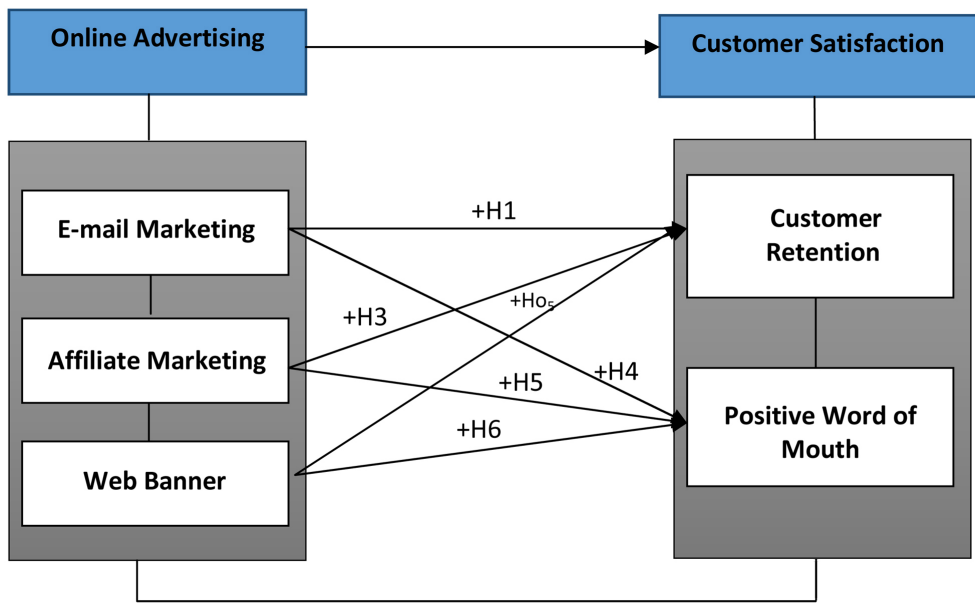

Figure 1. Operational conceptual framework of relationship between online advertising and customer satisfaction. Source: Researcher conceptualization from review of related literature, 2017. 
proposes three dimensions of online advertising as the in depended variable to include, e-mail marketing, affiliate marketing and web banner. The depended variables customer satisfaction is proposed to be measured by customer retention and positive word of mouth.

\section{Concept of Online Advertising}

As a means of information, persuasion and promotion, advertising has existed as a promotional mix element for several decades. Advertising is seen as an important and well known form of marketing communication, and as a communication tool, it uses various forms of mass media to get sales messages across large number of people. The traditional mass media for advertising is to, broadcasting, magazine and newspaper [7] [8] [9]. But, with fast development in information technology, the internet has turn to be good advertising media that is commonly used by advertisers and markets to share messages to consumers [10]. Internet advertising, (Also known as online advertising) "is the delivery of advertising message and marketing communication through websites". It can be through various electronic platforms such as mobile phones, Ipads, desktop computers and laptops. Another author defined online advertising as "a form of advertising which uses the internet to deliver promotional marketing messages to consumers. Online advertising uses the essential elements of traditional advertising, which is captured in advertising effectiveness model that in values four steps of action: attention, interest, desire and action (A I D A). The channels of communication in online advertising include the following: email marketing, media, social media, search engine marketing, affiliate marketing, pop-up, text-link, and mobile advertising, etc. It should be observed that for the mere fact that a company has a website on the internet, although it is a form of promotion, it cannot be considered as online advertising [11]. What constitutes advertising is the channel of attracting customers to the website. Like other advertising media.

Online advertising usually involves a publisher, that integrates advertisements into its content, an advertize that who provide the message to be displayed in the publishers context. Other participants include advertising agencies, that create and place the ad message and ad server that delivers ad and track statistical information. Marketers use online advertising as powerful and effective marketing tool to advertise their product or services [12]. Two main reasons online advertising is seen as powerful are first, is that most household have good access to internet. Secondly internet has audiences that uses or access internet on daily basis, which is different from traditional advertising [12]. Internet is targeted at reaching its audience by creating awareness about a brand and having immediate response [12]. Online advertising aid companies to sale their products and services through one-on-one interaction with companies and their customers. According to [12], online advertising helps marketers to facilitate the marketing of their product or services locally and abroad, it also enhances consumers purchases from both home and international in more, effective ways [11]. Online 
advertising effectiveness help marketers to make use of internet, make changes of their messages that can help them gain more customers [13]. Ability to marketers to detect changes and connect it makes advertisement more effective. Effectiveness of advertising is the ability of the advertiser to present the message in such away there be will interaction between sellers and buyers [14]. Because customers link to engage interactive advertisement. Recent study shows that customer are more informed and do not need third party (middleman) and the solution is to have advert that interact freely among buyers and sellers without. [12] said that if customer understanding the message very well, it enhances the company image, profitability, and makes them to stand out for competitions.

Online advertising has a lot of benefits for both merchants and the customers which are as follows: Online advertising is easily accepted by consumers than advertising through television and radio which may disturb consumer or comes in an unexpected way. It is also acceptable to surfers because they have the power to control the time when, they certain amount of information they drive from the site [15]. It is cheaper compare to other media, marketers may gain exposure to a good number targeted audience at a lower cost and found group of customers that shared the same interest. Interactivity of the internet is another significant factor that allows users to express their reaction to the advertisers by a clicking [6]. Coverage is another major advantages of online advertising of the elimination of geographical limitation. Internet provides unlimited global reach for marketers, hence every person in any part of the world that have internet access can be reached with ease. Cost effective compared to traditional advertising, internet advertising is much more cost effective. It does not need much financial investment to deliver marketing messages through the internet. Online advertising has the ability to deliver immediately the design is ready and customers receive them immediately. Online advertising is characterized with real-time interaction between the advertise and users. This can lead to instant result from the advertising efforts. Effectiveness of the characteristics of online advertising is that marketing tools are designed to target specific set of customers or group. This enables it deliver marketing messages to targeted customers who are interested in and the products or services, rather than a general public. Internet advertising results are easily measurable and available in real time. Each click, visit to the websites, sign ups, online purchases can be measured very accurately for marketing analysis and improvement of advertising campaign where necessary. Online advertising is available 24 hours in a day, 7 days in a week and 365 days in a year. This allows small business to compete in the digital market place with major companies [15].

Internet provides advertiser with different ways of delivering their promotional messages, such as videos, images, audio, links etc. It is also interactive as customers are allowed to connect through social media and make some input and suggestions. Despite the above mentioned advantages of online advertising, the following are some of the disadvantages: Internet advertising is highly de- 
pendent on technology. If there is break down in technology, it can provide erroneous results that can severely affect the advertising campaign. For instance, non-working links to important pages in website, non-function order button, can lead to loss of business. Lack of trust by customers especially in the developing world, is a major challenge to online advertising campaign. Several people still mistrust electronic method of paying, and feared whether ordered goods can be received. The proliferation of online advertising leads to too much competition in the digital market place. And marketers are fiercely competing for a better positioning of their adverts for better visibility of the advertising campaign. Online advertising some marketing campaign can easily be copied by a competitor trademarks or logos can be used to defraud customers and send numerous information against company products or services, which can ruin a company reputation. Online advertising for purchase of products and services through internet is not adapted by all. Some people still refer traditional brick and mortar store where they can touch and examine products before purchasing. Lack of user privacy. Despite all this disadvantages internet users still believe that internet is reliable, efficient and effective tools in achieving goals, performing tasks, and information processes and dissemination. The major means of online advertising according to [16].

There are different formats of advertisements found in the internet. They are sponsorship, keyword linking, commercial sites, pop-up advertising and banners. Sponsors currently, online sponsorships has moved from $24 \%$ to $37 \%$ of all new means of interactive media, it appears in a special or specific section in the site but at the same time helps advertisers to be clear for marketing purposes.

\section{Dimensions of Online Advertising}

There are many dimensions of online advertising such as e-mail marketing, social media marketing, affiliate marketing, search engine marketing, texts messages, display advertising and mobile advertising by many authors. But for the purpose of this research work, we shall focus on e-mail marketing, affiliate marketing, and web banner.

\subsection{E-Mail Marketing}

E-mail has gain dominance in the field of business through internet and through this cost is reduced. Because of this as an advantage many marketing practitioners has decided to adopt the use of internet. E-mail is targeted to specific group of customers in order to satisfy their personal needs [5]. E-mail is used to reach large number of customer with a high rate of response [16]. Companies profit are increasing, they were gaining more attention and awareness through the use of e-mail [17]. E-mail marketing is a way of reaching consumers directly through electronic mail to deliver messages or as a means of communicating for commercial purposes [18]. Corporation value good e-mail messages. Owners of business are using e-mail in their marketing activities so as to enhance effective 
performance, increase return of investment (ROI), gain access by consumers and reduced cost that will be incurred by traditional means [19]. Benefit of e-mail marketing is that it builds excellent relationship among marketers and their consumers. It builds quality communication to customers and good feedback to organization [19]. E-mail marketing to have a direct marketing with their customers through e-mail. Marketers also gain a better knowledge of their customer's needs and wants [18]. According to [18], e-mail is said to be a direct means to online marketing that increases benefit of the firm. [5] state the following benefits which are as follows: -Reduction of promotional cost; conversation among firms and customers are increased; facilitation online transactions; immediate feedback are gotten from customers; helps create awareness about the product and service; and increases traffic.

\subsection{Affiliate Marketing}

Affiliate marketing is effective tool of online marketing [20]. [15] said that it is a kind of program that permits partner or affiliate to advertise product of merchants. He went further to state that this kind of marketing includes compensation which can be ascertained through rate of clicks. The first affiliate marketing was developed by CDNow.com and Amazon.com in 1994. Their idea is centered on win bases [21]. It is a kind of marketing that is based on agreement, the merchant paid the affiliate. Some amount of commission [15]. The merchant paid the affiliate when customer's purchases through the affiliate site [20]. [15] state that marketers lose nothing, even if there is decrease in sales or fraudulent issues because commission depend on sale. In Affiliate marketing merchants reach agreement with the affiliates on the commission to be paid on each sale of the product bought through their efforts [22]. [22] also said currently, that the type of affiliate programs we have these days can be set up easily and earn instant profit for the company.

\subsection{Web Banner}

Web banner is a platform on a web page [23]. Web banner is grouped into animated or statistics banner [22]. Different banner effectiveness has been carried out by scholars in different locations [24], some literatures has stated it that no matter how beautiful a banner is, it has effect on consumers and that they are not likely to look at banners when they are busy or have something else to look on the web [23] while other literature argues that banner has great effects on consumers responses. Consumers that click frequently is likely to be attracted by quality banners [24]. Web marketing is an investment to companies that uses banner for advertisement instead of traditional means that will cost more [25]. Online can be measured while offline cannot be measured.

For example, the use of web banner can be record or measured the number of clicks [26]. Number of clicks is used to know how effective banner advertisement its [27]. Banner advertisement has the power to move the browser from the 
original page from which the browser can access information to the advertise products and services to where the browser will take action [26]. Web banner in small size of clickable pages can later develop into bigger sizes (Plummer et al., 2007). Different web banner sizes according to Advertising Bureau 2011. They include: $300 \times 250$ Imu (Medium Rectangle); $180 \times 150$ Imu (Rectangle); $728 \times$ 90 Imu (Leader Board); $160 \times 600$ Imu (Wide Skyscraper); $300 \times 600$ Imu (Half Page); $120 \times 60 \mathrm{Imu}$ (Button); $88 \times 31 \mathrm{Imu}$ (Micro Bar). Web banner should be attractive to majority of web users because of the way is being presented.

\section{Measures of Customer Satisfaction}

In measuring satisfaction as indicated by [28] certain indicator's has to be considered. According to [28] measures customer Satisfaction as repeat purchase; loyalty; positive word-of-mouth and increased long term profitability, he uses four measures for his own while [9] uses three measures like positive word-of-mouth, retention and loyalty. [28] used loyalty and positive wordof-mouth, therefore is seen alignment between Kotler (2000) and Wirtz the measures for this study is deduced to: retention and; positive word-of-mouth. Negativity Theory of Customer Satisfaction. This theory which was propounded by [29] states that any variation in performance from expectation will disrupt the individual, thereby producing "Negative Energy", it has its root in the disconfirmation process. This theory asserts that if customers' expectations are strategy held, consumers will respond negatively to any disconfirmation and dissatisfaction is likely to occur if performance is less than expectations but if performance is more than expectations, satisfaction will occur. Therefore in e-tailing firms if customers are satisfied they will repeat purchase.

\subsection{Customer Satisfaction}

The major aim for establishing a company is to make profit through products and services, purchases by consumers. Products and services are being developed by firms and they map out appropriate strategies in offering the products and services to targeted customers. The targeted customers get convinced and make purchase for use and satisfy their needs. When targeted customers are satisfy with the product and services they keep on making purchases. Customer satisfaction can said to mean a process or an outcome. The rate at which firms' products are purchased by consumers and quality online practices result to customer satisfaction retention, huge patronage and loyalty to organization [30]. Once a customer is satisfied is likely to remain loyal to the company's product and will repeat purchase, he will also went further to spread the good experience to potential customers (WOM) [31].

Through satisfaction of customers companies achieve their goals. Satisfaction is said to be a person's feeling of pleasure or disappointment which is as a result of comparison of a product perceived performance in relation with his or her expectations [6]. Therefore customer satisfaction can be defined as a result of 
cognitive and affective evaluation, in which some comparison are made between the actual compared standard and perceived performance. If performance is less than excepted customer will be dissatisfied but if performance is more than accepted the customer will be satisfied. Customers will be in neutral stage if perceived expectations met performance. [32] assert that customer satisfaction is the customers' evaluation of performance offering to date. The overall satisfaction has strong positive effect on customer loyalty intensions over a wide range of product and services. Sales process, after-sale service, customers expectation and whether customer is satisfied after purchase depends offering of the product and customer expectation. Expectation can be form by customers from their past experience, friends, associates advice, marketers, competitors' information and promises. Expectation are being determined by customers' needs, total value and total cost. Choosing a product or service is among the stages customers go through. Buyer's characteristics influence its decision, such as culture, social, personal and psychological factors. The process is in five stages: 1) new recognition, 2) information search, 3) information evaluation, 4) purchase decisions and 5) post purchase evaluation. Information search is the key to consumer's decision-making process which can be for both internal and external information.

Consumers continue to search for information because of risk in order to meet up the uncertainties of potential positive or negative consequences. At times customers passes through all the five stages or they may skip some. But customer is looking for is value in the product they are buying. Customers seek for information about the product they want to buy to check if it is in line with their expectations and if the product or service is of essential importance, they check these through surveys, phone interviews and customer discussions. Customer orientation is also important and need to be measured constantly [15]. Customer being the "life blood" of every business and at the same the reason while business are established need satisfaction from product and services they purchase from the firm. Many studies have shown that it is difficult to measure customer's satisfaction but at the same time it has some favorable attributes such as repeat purchase behavior and positive word of mouth.

\subsection{Retention}

Customer retention is noted to have it own foundation from planned behavior theory and it is a response of consumers to brands, services, product and activities [33]. Customer retention and customer loyalty are being used interchangeably, customer retention was first develop by Reichheld and Sasser in 1990 further more customer retention and loyalty are not each other substitutes because they are different [34]. [35] state that retention is continuation of business with a particular company on ongoing basis. Customer retention involves the first four emotional cognitive retention constructs and last two behavioral intentions. Customer retention can be defined as the maintenance of continuous trading relationships with customers over the long term. 
[36] state that customer retention involves repeat patronage and this is closely related to repeat-purchasing behavior, and brand loyalty. [37] stated that commitment is important in business relationship because, it ensures strength, stability, durability, profitability of relationship. For there to be retention the firm and customer has to be in relationship studies have shown that the meaning and measure of customer retention varies. There is a lot of benefits to gain for firms that focuses on customer retention, such as increase in profit margin, faster growth and good returns [18] [35].

\subsection{Positive Word of Mouth}

Positive word of mouth is known as powerful methods in marketing from aspect of customers. The idea of word of mouth marketing brings value to marketing world of business positive word of mouth is easy to maintain customer loyalty and increase customer base [38]. The author also confirms that a relationship exist between word of mouth and customer loyalty. Word of mouth is spreading of good news about product and services between people apart from company's advertisement for products or services [39] state that people persuade others to buy because of the benefit they have gotten form the product. [40] asserted that effect of positive or negative word of mouth on consumer's differs from industry to industry. [41] stated that word of mouth is more than saying about the product. Because people trust what they here directly from relatives, friends and colleagues advices more than mass media [42]. Higher quality of product and services offered to customers brings about positive word of mouth, brand loyalty, retention and repeat purchase behavior. Commitment brings about word of mouth marketing [43]. [44] stated that the greater the consistency between brand image and consumer's self image, the higher consumer evaluation in brand and willingness to buy the brand.

\section{Relationship between Online Advertising and Customer Satisfaction}

\subsection{E-Mail Marketing and Customer Satisfaction}

E-mail has gained much dominion in the field of business, and this can be very much cost effective. Because of this benefit many marketing practitioners has started adopting the use of internet. E-mail is used to reach specific group of customers and to satisfy their individual needs and wants [44]. It is used to reach large number of customers on personal bases and the response rate is high [26]. E-mail has helped to increase the quality of services rendered to customers and also increase company's profit. The use of E-mail marketing has also helped in drawing customer attention [26]. E-mail marketing is used to deliver message direct to customers for transaction basis. Business owners use email to perform marketing activities, to reduce cost that can be incurred through traditional means, to acquire large return on investment (ROL), to gain access easily by consumers and can be cheap to undertake [43]. According to [45] email mar- 
keting benefit assist marketers to build excellent relationship between them and their consumers. And also help them provide quality communication to consumers, to have better knowledge of their customers and their individual needs and wants [46]. E-mail helps companies to get immediate feedback from consumers and to make needed adjustment where necessary. Some of the benefits of e-mail are: Lowers promotion experiences, it helps customers to perform, online transaction and it increases customer awareness etc. and also inform customers about company's product and services that will satisfy needs and wants with a good quality. Literatures have shown factors that could encourage customer satisfaction through internet usage [47] brand image issues [48] customer value [49], customer service [41]. On this note, the study hypnotizes that:

$\mathrm{Ho}_{1}$ : There is no significant relationship between e-mail marketing and customer retention of e-tailing firms in Nigeria.

$\mathrm{Ho}_{2}$ : There is no relationship between e-mail marketing and positive word of mouth of e-tailing firms in Nigeria.

\subsection{Affiliate Marketing and Customer Satisfaction}

Affiliate marketing is a powerful tool of online marketing [50]. [26] stated that affiliate programs are ways in which marketing allows partner or partners to advertise product of the merchant. He stated further that this kind of marketing can also be seen as a performance marketing because it includes compensation which can be done through the rate of clicks. In 1994 was when the first affiliate took place by CDNow Program and was developed by CDNow.com and Amazon.com. Main idea of this market program is on win/won bases [15]. This type of marketing is also based on agreement because the firm/merchant has decided to pay the affiliate certain amount of commission [13]. The benefit is that whenever customers purchase through the affiliate commission is earned by the affiliate [15]. [19] assert that a marketer has nothing to use in case of fraudulent activities and decrease in sales, hence commission is dependent on sale. The kinds of affiliate we have these days are easily to set up and has the ability to command instant profit for the company [18]. Affiliate marketing has changed the way in which business is being carried on the web and online. Affiliate marketing increases the chances of marketers reaching their targeted audience. Reduction of cost of operation and increase on return on investment is being achieved by affiliate marketing [51]. Quality online practices result to customer satisfaction, huge patronage, retention and can influence loyalty to the organization [51]. Satisfied customers are convinced to remain loyal with the company, and are likely to repeat purchasing the company's offering. He went ahead to spread the good experience to potential customers (WOM) [48]. Firms achieved their goals through constant purchases by satisfied customers. Customers will continue to purchase the offerings of the company since is satisfying their needs value and want. Literatures have show factors that enhance customer satisfaction such as listening to customers complain and resolving it satisfactorily. The firms 
make available suggestion forms, toll-free numbers, web sites, e-mail addresses for quick response from the firm and allow two- way communication [19]. On this note, the study hypnotizes that:

$\mathrm{Ho}_{3}$ : There is no significant relationship between affiliate marketing and customer retention of e-tailing firms in Nigeria.

$\mathrm{Ho}_{4}$ : There is no significant relationship between affiliate marketing and positive word of mouth of e-tailing firms in Nigeria.

\subsection{Web Banner and Customer Satisfaction}

[18] state that banners has minimum effect on consumers, because when consumers are busy with something else on the web, they do not look at banner no matter how beautiful and colourful it appears. Even though other literatures argue that banner advertisement can be of great effects, quality banners attract huge number of consumers who click frequently [1]. Traditional means bring cost to marketers while web marketing or banner advertisement is an investment to marketing. Online marketing can be measured while offline cannot be measured. Web marketing records the number of clicks [52]. Banner advertisement is capable of moving the browser from original web page to where the browser can access information about the advertised products and service [51]. Web banners can be small size of clickable pages which later develops into bigger page sizes and shapes [47]. Satisfied customers show loyalty by repeating purchase and also spread good word of mouth [19]. With the use of internet people can spread bad or good news with easy therefore companies should try as much as they can to provide quality product and service in order to retain their customers. Trust and self-efficacy on the part of company increase increases profit [52]. On this note, the study hypotizes that:

$\mathrm{Ho}_{5}$ : There is no relationship between web banner and customer retention of e-tailing firms in Nigeria.

$\mathrm{Ho}_{6}$ : There is no relationship between web banner and positive word of mouth of e-tailing firms in Nigeria.

\section{Research Design}

The study, empirically seeks to evaluate the influence of online advertising on customers satisfaction of e-tailing firms in Nigeria. It is a survey study, which adopt quasi- experimenter design, through the help of cross-sectioned survey to collect data from the study elements in different point so as to make a logical generalization. The study is of sociological debate, which means that the study deals with social sciences/behavior. It is a non-contrived study, which implies that the researcher was not in control of the study elements. The world internet Statistics (2017) shows that the population of online users as at March 2017 is $191,836,936$ [42]. However the population on social network is $16,000,000$. Since this study is focused on online advertising and social media (e-mail, affiliate and web banner). Therefore $16,000,000$ is the population of online users in Nigeria. 
[42] sample size determination table was used to determine the sample size of 384. The instrument used to collect the most relevant data is through the use of constructed questionnaire, personal oral interview and observation. The instrument is made up of three different sections: A, B and C. Section A: are questions bordering on the respondents demographics which consist of seven (7) questions. Section B: is made up of questions on the predictor variable (online advertising), which consists of (15) questions. Finally, Section C: are questions on the criterion variable (customer satisfaction), it has (10) questions. The instrument adopts a five point scale: strongly agree $(\mathrm{SA})=5$, agree $(\mathrm{A})=4$, disagree $(\mathrm{D})=3$, strongly disagree $(\mathrm{SD})=2$ and Undecided $(\mathrm{U})=1$.

As can be seen in Table 1, all the dimensions of online advertisement and the measures of satisfaction of e-tail firms are reliable given a reliability coefficient greater than 0.7 [42]. Email marketing has a reliability alpha of 0.76 , affiliate marketing 0.77 , web banner 0.74 , customer retention 0.79 and positive word of mouth 0.76 . This suggests that the dimensions can be used for further statistical analysis.

As can be seen in Table 2 the descriptive statistics on items of E-Mail Marketing is shown. Specifically, the table revealed that: Our cost of advertising is now reduced had a mean of 3.94 and standard deviation of 1.160. E-mail helps us to target a particular segment of customers had a mean of 3.73 and a standard

Table 1. Result of reliability analysis.

\begin{tabular}{cc}
\hline VARIABLE & CRONBACH'S ALPHA \\
\hline E-mail Marketing & 0.768 \\
Affiliate Marketing & 0.772 \\
Web Banner & 0.742 \\
Customer Retention & 0.792 \\
Positive Word of Mouth & 0.764 \\
\hline
\end{tabular}

Source: SPSS 20.0 Output (based on 2017 field survey data).

Table 2. Descriptive statistics on items of e-mail marketing.

\begin{tabular}{|c|c|c|c|c|}
\hline \multicolumn{5}{|c|}{ Descriptive Statistics } \\
\hline Questionnaire Items & $\mathbf{N}$ & Sum & Mean & $\begin{array}{c}\text { Std. } \\
\text { Deviation }\end{array}$ \\
\hline Our cost of advertising is now reduced & 285 & 1123 & 3.94 & 1.160 \\
\hline $\begin{array}{l}\text { E-mail helps us to target a particular } \\
\text { segment of customers }\end{array}$ & 285 & 1062 & 3.73 & 1.205 \\
\hline $\begin{array}{l}\text { It helps our esteemed customers to gain } \\
\text { easy access }\end{array}$ & 285 & 1014 & 3.56 & 1.387 \\
\hline Our customer traffic is on the increase & 285 & 1046 & 3.67 & 1.212 \\
\hline It reduces cost of haulage & 285 & 1069 & 3.75 & 1.238 \\
\hline Valid N (listwise) & 285 & & & \\
\hline
\end{tabular}

Source: SPSS 20.0 Output (based on 2017 field survey data). 
deviation of 1.205. It helps our esteemed customers to gain easy access had a mean of 3.56 and a standard deviation of 1.387. Our customers traffic is on the increase had a mean of 3.67 and a standard deviation 1.212 . It reduces cost of haulage had a mean of 3.75 and a standard deviation of 1.238.

The information in Table 3 shows the descriptive statistics on items of Affiliate Marketing. Specifically, the table revealed that: Our firm is increasing its sales through the advertising agency had a mean of 3.77 and a standard deviation of 1.146. Our product sales are on the increase had a mean of 3.72 and a standard deviation of 1.244. The use of affiliate marketing has helped our firm to remain competitive had a mean of 3.44 and a standard deviation 1.366. Affiliate marketing enhance profit margin had a mean of 3.51 and a standard deviation of 1.291. Affiliate marketing increases return of investment had a mean of 3.69 and a standard deviation of 1.200. The mean value of all the variables are greater than 3 , as such, the researcher upheld the prevalence of the study variables.

The information in Table 4 shows the descriptive statistics on items Web Banner. Specifically, table revealed that: Our banner online are very attractive had a mean of 3.91 and a standard deviation of 0.945 . Web banner convenience our target audience had a mean of 4.04 and a standard deviation of 0.952 . Online banner are of high quality in such a way that it engenders huge response had mean of 3.77 and standard deviation of 1.274. Web banner operations help increase awareness of our board had a mean of 3.50 and standard deviation of 1.331. Web banner makes advertising more attractive had a mean of 3.64 and standard deviation of 1.286. The mean value of all the variables are greater than 3 , as such, the researcher upheld the prevalence of the study variables.

The information in Table 5 shows the descriptive statistics on items of Customer Retention. Specifically, the table revealed that: Through quality online

Table 3. Descriptive statistics on items of affiliate marketing.

\begin{tabular}{ccccc}
\hline & Descriptive Statistics & & \\
\hline Questionnaire Items & N & Sum & Mean & $\begin{array}{c}\text { Std. } \\
\text { Deviation }\end{array}$ \\
\hline $\begin{array}{c}\text { Our firm is increasing its sales } \\
\text { thorough the advertising agency }\end{array}$ & 285 & 1074 & 3.77 & 1.146 \\
$\begin{array}{c}\text { Our product sales are on the increase } \\
\begin{array}{c}\text { The use of affiliate marketing has } \\
\text { helped our firm to remain } \\
\text { competitive }\end{array}\end{array}$ & 285 & 1060 & 3.72 & 1.244 \\
$\begin{array}{c}\text { Affiliate marketing } \\
\text { enhance profit margin }\end{array}$ & 285 & 980 & 3.44 & 1.366 \\
Affiliate marketing increase return \\
$\quad$ on investment
\end{tabular}

Source: SPSS 20.0 Output (based on 2016 field survey data). 
Table 4. Descriptive statistics on items of web banner.

\begin{tabular}{ccccc}
\hline Questionnaire Items & N & Sum & Mean & $\begin{array}{c}\text { Std. } \\
\text { Deviation }\end{array}$ \\
\hline $\begin{array}{c}\text { Our banners online are very attractive } \\
\text { Web banner convenience } \\
\text { our target audience }\end{array}$ & 285 & 1114 & 3.91 & 0.945 \\
$\begin{array}{c}\text { Online banner are of high quality in such } \\
\text { a way that it engenders huge response }\end{array}$ & 285 & 1152 & 4.04 & 0.952 \\
$\begin{array}{c}\text { Web banner operations help increase } \\
\text { awareness of our board }\end{array}$ & 285 & 1037 & 3.64 & 1.286 \\
$\begin{array}{c}\text { Web banner makes advertising more } \\
\text { attractive }\end{array}$ & 285 & 1069 & 3.75 & 1.238 \\
$\quad$ Valid N (listwise) & 285 & & & \\
\hline
\end{tabular}

Source: SPSS 20.0 Output (based on 2017 field survey data).

Table 5. Descriptive statistics on items of customer retention.

\begin{tabular}{ccccc}
\hline Questionnaire Items & N & Sum & Mean & $\begin{array}{c}\text { Std. } \\
\text { Deviation }\end{array}$ \\
\hline $\begin{array}{c}\text { Through quality online practices we } \\
\text { retain our customer via convenience } \\
\begin{array}{c}\text { Quick access to our web promotes } \\
\text { customer retention }\end{array}\end{array}$ & 285 & 1110 & 3.89 & 1.130 \\
$\begin{array}{c}\text { Through effective delivery customers } \\
\text { are retained }\end{array}$ & 285 & 1047 & 3.67 & 1.182 \\
$\quad \begin{array}{c}\text { Through effective marketing } \\
\text { relationship customer are retained } \\
\quad \begin{array}{c}\text { Through effective marketing } \\
\text { customers are satisfied }\end{array}\end{array}$ & 285 & 1037 & 3.64 & 1.331 \\
$\quad$ Valid N (listwise) & 285 & 1066 & 3.74 & 1.185 \\
\hline
\end{tabular}

Source: SPSS 20.0 Output (based on 2017 field survey data).

practices we retain our customer via convenience had a mean of 3.89 and a standard deviation of 1.130. Quick access to our web promotes customer retention a mean of 3.67 and a standard deviation of 1.182. Through effective delivery customers are retained had a mean of 3.54 and a standard deviation of 1.331 . Through effective marketing relationship customers are retained had a mean of 3.64 and standard deviation of 1.153 . Through effective marketing relationship customers are satisfied had a mean of 3.74 and standard deviation of 1.185 . The mean values of all the variables are greater than 3 .

Table 6 exhibits descriptive statistics on items of Positive Word of Mouth. Specifically, the table shows that: We are currently enjoying increased customer's base through the use of positive word mouth had a mean of 3.93 and a standard deviation of 1.142. Because of how satisfied our customers are, they consciously, positively patronize us had a mean of 3.74 and a standard deviation of 
Table 6. Descriptive statistics on items of positive word of mouth.

\begin{tabular}{ccccc}
\hline Questionnaire Items & N & Sum & Mean & $\begin{array}{c}\text { Std. } \\
\text { Deviation }\end{array}$ \\
\hline $\begin{array}{c}\text { We are currently enjoying increased } \\
\text { customer's base through the use of } \\
\text { positive word of mouth }\end{array}$ & 285 & 1120 & 3.93 & 1.142 \\
$\quad \begin{array}{c}\text { Because of how satisfied our } \\
\text { customers are, they consciously, } \\
\quad \text { positively patronize us } \\
\begin{array}{c}\text { My firm is benefiting from a } \\
\text { quality service }\end{array}\end{array}$ & 285 & 1066 & 3.74 & 1.191 \\
$\begin{array}{c}\text { With positive ward of mouth, return } \\
\text { on investment (ROI) is at increase }\end{array}$ & 285 & 1042 & 3.66 & 1.396 \\
$\quad \begin{array}{l}\text { With positive words of mouth } \\
\text { customers are retained }\end{array}$ & 285 & 1082 & 3.80 & 1.205 \\
$\quad$ Valid N (listwise) & 285 & & & \\
\hline
\end{tabular}

Source: SPSS 20.0 Output (based on 2017 field survey data).

1.191. My firm is benefiting from a quality service had a mean of 3.52 and a standard deviation of 1.396. With positive word of mouth, return of investment (ROI) is at increase had a mean of 3.66 and a standard deviation of 1.211 . With positive word of mouth our customers are retained had a mean of 3.80and a standard deviation of 1.205 .

\section{Hypotheses Testing}

Table 7 shows that the spearman's correlation coefficient of the association between Online-Advertising and Customer Satisfaction is $0.753^{\star *}$. This value is strong, implying that a strong relationship exist between the variables. The positive sign of the correlation coefficient means that a positive relationship exists between online-advertising and customer satisfaction, implying that an increase in online-advertising will result to an increase in customer satisfaction.

$\mathrm{HO}_{1}$ : There is no significant relationship between e-mail marketing and customer retention. Table 8 shows a positive relationship between E-Mail Marketing and Customer Retention. The test produced $0.891^{\star *}$ score in the spearman's rank order coefficient, which means that the relationship between the variable is a very strong one. Based on this result, the null hypothesis is rejected and the alternate is accepted.

$\mathrm{HO}_{2}$ : There is no significant relationship between e-mail marketing and positive word of mouth. Table 9 shows that spearman's rank order coefficient correlation of the relationship between E-Mail Marketing and Positive Word of Mouth is $0.930^{\star *}$. The value is very strong implying that a very strong relationship exists between the variables. The positive sign of the correlation coefficient implies that a positive relationship exists between E-Mail Marketing and Positive Word of Mouth. Thus the null hypotheses are rejected and we accept the alternate 
Table 7. Correlation analysis showing the relationship between online-advertising and customer satisfaction.

\begin{tabular}{ccccc}
\hline \multirow{2}{*}{ Type } & \multicolumn{3}{c}{ Correlations } & \\
\hline Variables 1 & Statistics & $\begin{array}{c}\text { Online } \\
\text { advertising }\end{array}$ & $\begin{array}{c}\text { Customer } \\
\text { Satisfaction }\end{array}$ \\
\hline \multirow{2}{*}{ Spearman's rho } & Online advertising & $\begin{array}{c}\text { Correlation } \\
\text { Coefficient }\end{array}$ & 1.000 & $0.753^{*}$ \\
& Sig. (2-tailed) & - & 0.000 \\
Customer & $\mathrm{N}$ & 285 & 285 \\
Satisfaction & $\begin{array}{c}\text { Correlation } \\
\text { Coefficient }\end{array}$ & $0.753^{*}$ & 1.000 \\
& Sig. (2-tailed) & - & 0.000 \\
& $\mathrm{~N}$ & 285 & 285 \\
\hline
\end{tabular}

${ }^{*}$ Correlation is significant at the 0.01 level (2-tailed). Source: SPSS 20.0 Output (based on 2017 field survey data).

Table 8. Correlation analysis showing the relationship between e-mail marketing and customer retention.

\begin{tabular}{ccccc}
\hline \multicolumn{1}{c}{ Type } & Correlations & & \\
\hline Vpearman's rho & E-Mail Marketing 1 & Statistics & $\begin{array}{c}\text { E-Mail } \\
\text { Marketing }\end{array}$ & $\begin{array}{c}\text { Customer } \\
\text { Retention }\end{array}$ \\
\hline & $\begin{array}{c}\text { Correlation } \\
\text { Coefficient }\end{array}$ & 1.000 & $0.891^{* *}$ \\
& Sig. (2-tailed) & - & 0.000 \\
Customer & $\mathrm{N}$ & 285 & 285 \\
& Retention & $\begin{array}{c}\text { Correlation } \\
\text { Coefficient }\end{array}$ & $0.891^{*}$ & 1.000 \\
& Sig. (2-tailed) & 0.000 & - \\
& $\mathrm{N}$ & 285 & 285 \\
\hline
\end{tabular}

${ }^{*}$ Correlation is significant at the 0.01 level (2-tailed). Source: SPSS 20.0 Output (based on 2017 field survey data).

hypotheses. This means that an increase in E-mail Marketing and will result to an increase in Positive Word of Mouth.

$\mathrm{HO}_{3}$ : There is no significant relationship between affiliate marketing and customer retention.

Table 10 indicates a positive relationship between Affiliate Marketing and Customer Retention. The test result of 0.463 indicates a moderate relationship between affiliate marketing and customer retention. Consequently this study accepts the alternate hypotheses and rejects the null hypotheses. This implies that there is a positive and significant relationship between affiliate marketing and customer retention.

$\mathrm{HO}_{4}$ : There is no significant relationship between affiliate marketing and positive word of mouth. Table 11 shows a positive relationship between affiliate 
Table 9. Correlation analysis showing the relationship between e-mail marketing and positive word of mouth.

\begin{tabular}{ccccc}
\hline Type & Variables 1 & Statistics & $\begin{array}{c}\text { E-Mail } \\
\text { Marketing }\end{array}$ & $\begin{array}{c}\text { Positive } \\
\text { Word of } \\
\text { Mouth }\end{array}$ \\
\hline Spearman's rho & E-Mail Marketing & $\begin{array}{c}\text { Correlation } \\
\text { Coefficient }\end{array}$ & 1.000 & $0.930^{*:}$ \\
& $\begin{array}{c}\text { Sig. (2-tailed) } \\
\text { N }\end{array}$ & - & 0.000 \\
& $\begin{array}{c}\text { Positive Word of } \\
\text { Mouth }\end{array}$ & $\begin{array}{c}\text { Correlation } \\
\text { Coefficient }\end{array}$ & $0.930^{* *}$ & 1.000 \\
& $\begin{array}{c}\text { Sig. (2-tailed) } \\
\mathrm{N}\end{array}$ & 0.000 & - \\
& & 285 & 285 \\
\hline
\end{tabular}

${ }^{* *}$ Correlation is significant at the 0.01 level (2-tailed). Source: SPSS 20.0 Output (based on 2017 field survey data).

Table 10. Correlation analysis showing the relationship between affiliate marketing and customer retention.

\begin{tabular}{ccccc}
\hline Type & Variables 1 & Statistics & $\begin{array}{c}\text { Affiliate } \\
\text { Marketing }\end{array}$ & $\begin{array}{c}\text { Customer } \\
\text { Retention }\end{array}$ \\
\hline \multirow{2}{*}{ Spearman's rho } & Affiliate Marketing & $\begin{array}{c}\text { Correlation } \\
\text { Coefficient }\end{array}$ & 1.000 & $0.463^{* *}$ \\
& Sig. (2-tailed) & - & 0.000 \\
& $\mathrm{~N}$ & 285 & 285 \\
& Customer Retention & $\begin{array}{c}\text { Correlation } \\
\text { Coefficient }\end{array}$ & $0.463^{* *}$ & 1.000 \\
& $\begin{array}{c}\text { Sig. (2-tailed) } \\
\end{array}$ & $\mathrm{N}$ & 0.000 & - \\
& & 285 & 285 \\
\hline
\end{tabular}

${ }^{* *}$ Correlation is significant at the 0.01 level (2-tailed). Source: SPSS 20.0 Output (based on 2017 field survey data).

Table 11. Correlation analysis showing the relationship between affiliate marketing and positive word of mouth.

\begin{tabular}{|c|c|c|c|c|}
\hline Type & Variables 1 & Statistics & $\begin{array}{c}\text { Affiliate } \\
\text { Marketing }\end{array}$ & $\begin{array}{c}\text { Positive } \\
\text { Word of } \\
\text { Mouth }\end{array}$ \\
\hline \multirow[t]{6}{*}{ Spearman's rho } & Affiliate Marketing & $\begin{array}{l}\text { Correlation } \\
\text { Coefficient }\end{array}$ & 1.000 & $0.535^{\star *}$ \\
\hline & & Sig. (2-tailed) & - & 0.000 \\
\hline & & $\mathrm{N}$ & 285 & 285 \\
\hline & $\begin{array}{c}\text { Positive Word of } \\
\text { Mouth }\end{array}$ & $\begin{array}{c}\text { Correlation } \\
\text { Coefficient }\end{array}$ & $0.535^{\star *}$ & 1.000 \\
\hline & & Sig. (2-tailed) & 0.000 & - \\
\hline & & $\mathrm{N}$ & 285 & 285 \\
\hline
\end{tabular}

${ }^{*}$ Correlation is significant at the 0.01 level (2-tailed). Source: SPSS 20.0 Output (based on 2017 field survey data). 
marketing and positive word of mouth. The spearman's correlation coefficient result of $0.535^{* *}$ denotes a moderate relationship between affiliate marketing and positive word of mouth. Consequently, this study rejects the null hypothesis and accepts the alternate hypothesis. This implies that there is a relationship between affiliate marketing and positive word of mouth.

$\mathrm{HO}_{5}$ : There is no significant relationship between web banner and customer retention.

Table 12 shows a positive relationship between web banner and customer retention. The spearman's correlation coefficient result of $0.553^{* *}$ denotes a moderate relationship between web banner and customer retention. Consequently, this study rejects the null hypothesis and accepts the alternate hypothesis. This implies that there is a relationship between web banner and customer retention.

$\mathrm{H}_{6}$ : There is no significant relationship between web banner and positive word of mouth. Table 13 shows a positive relationship between web banner and

Table 12. Correlation analysis showing the relationship between web banner and customer retention.

\begin{tabular}{ccccc}
\hline Type & Variables 1 & Statistics & $\begin{array}{c}\text { Web } \\
\text { Banner }\end{array}$ & $\begin{array}{c}\text { Customer } \\
\text { Retention }\end{array}$ \\
\hline \multirow{2}{*}{ Spearman's rho } & Web Banner & $\begin{array}{c}\text { Correlation } \\
\text { Coefficient }\end{array}$ & 1.000 & $0.553^{* *}$ \\
& Sig. (2-tailed) & - & 0.000 \\
& $\mathrm{~N}$ & 285 & 285 \\
& Customer Retention & $\begin{array}{c}\text { Correlation } \\
\text { Coefficient }\end{array}$ & $0.553^{* *}$ & 1.000 \\
& Sig. (2-tailed) & 0.000 & - \\
& $\mathrm{N}$ & 285 & 285 \\
\hline
\end{tabular}

${ }^{*}$ Correlation is significant at the 0.01 level (2-tailed). Source: SPSS 20.0 Output (based on 2017 field survey data).

Table 13. Correlation analysis showing the relationship between web banner and positive word of mouth.

\begin{tabular}{ccccc}
\hline \multirow{2}{*}{ Type } & Variables 1 & Statistics & $\begin{array}{c}\text { Web } \\
\text { Banner }\end{array}$ & $\begin{array}{c}\text { Customer } \\
\text { Retention }\end{array}$ \\
\hline \multirow{2}{*}{ Spearman's rho } & Web Banner & $\begin{array}{c}\text { Correlation } \\
\text { Coefficient }\end{array}$ & 1.000 & $0.572^{\star \prime}$ \\
& Sig. (2-tailed) & - & 0.000 \\
& $\mathrm{~N}$ & 285 & 285 \\
& Customer Retention & $\begin{array}{c}\text { Correlation } \\
\text { Coefficient }\end{array}$ & $0.572^{*}$ & 1.000 \\
& Sig. (2-tailed) & 0.000 & - \\
& $\mathrm{N}$ & 285 & 285 \\
\hline
\end{tabular}

${ }^{*}$ Correlation is significant at the 0.01 level (2-tailed). Source: SPSS 20.0 Output (based on 2017 field survey data). 
positive word of mouth. The spearman's correlation coefficient result of $0.572^{\star *}$ denotes a moderate relationship between web banner and positive word of mouth. Consequently, this study rejects the null hypotheses and accepts the alternate hypotheses. This implies that there is a relationship between web banner and positive word of mouth.

\section{Discussion of Findings}

The findings of this study were drawn from discussion of the results in the previous. In this section, we discussed the findings to draw our conclusions as it were. However, we discussed the findings in three compartments according to the three basic dimensions of the predictor variable against the criterion variable.

\subsection{Association between E-Mail Marketing and Customer Satisfaction}

The findings associated to the relationship between e-mail marketing and customer satisfaction, show positive and significant influence. This is therefore related to the contention of [53], that e-mail marketing is a way of reaching consumers directly through electronic mail to deliver messages or as a means of communicating for commercial purposes. E-mail is used to reach large number of customer with a high rate of response [18]. Companies profit are increasing, they were gaining more attention and awareness through the use of e-mail [18]. For e-mail marketing to work, it needs to get a favourable beginning that allows it builds excellent relationship among marketers and their consumers, builds quality communication to customers and good feedback to organization, and have a direct marketing with their customers through e-mail. Marketers also have to gain a better knowledge of their customer's needs and wants. Based on the discussion of our findings an appreciable level of relationship exists in the e-tailing firms in Nigeria.

\subsection{Association between Affiliate Marketing and Customer Satisfaction}

The findings of the study related to the relationship between affiliate marketing and customer satisfaction, show positive and significant influence. The findings corroborate with the views of [16] that affiliate marketing is effective tool of online marketing and it helps firm to reach their targeted audience by increasing the awareness and presence of the firm. Affiliate marketing has a lot of benefits such as creating awareness of the brand; increasing companies return on investment and reduces cost of operation [25]. [22] said that it is a kind of program that permits partner or affiliate to advertise product of merchants. He went further to state that this kind of marketing includes compensation which can be ascertained through rate of clicks. The usage of affiliate activities this day has changed the way business is being carried on the web and it is useful for online marketing firms [38]. 


\subsection{Association between Web Banner and Customer Satisfaction}

The findings of the study related to the relationship between web banner and customer satisfaction, show positive and significant influence. The findings corroborate with the views of [54] that web banner is the most powerful and effective means, marketers used to promote their product and services. Web marketing is an investment to companies that uses banner for advertisement instead of traditional means that will cost more [39]. Different banner effectiveness has been carried out by scholars in different locations ([17], some literature has stated it that no matter how beautiful a banner is, it has effect on consumers and that they are not likely to look at banners when they are busy or have something else to look on the web [18] while other literature argues that banner has great effects on consumers responses. [55] said that internet advertisement through banner has a lot benefits and great exposure to the firm and marketers. Our results also show that web banner is a strategic marketing tool that is predominantly market driven geared toward enhancing the customer satisfaction of the company if properly applied and utilized.

\section{Summary}

In summary, the result of this study revealed that:

There is a positive and strong relationship between online advertising and customer satisfaction; and online advertising significantly affects customer satisfaction.

There is a very high indication that a very strong relationship exists between e-mail marketing and customer retention; and e-mail marketing significantly affects customer retention.

There is a very high indication that a very strong relationship exists between e-mail marketing and positive word of mouth; and e-mail marketing significantly affects positive word of mouth.

$>$ There is a positive and moderate relationship between affiliate marketing and customer retention; and affiliate marketing significantly affects customer retention.

There is a positive and moderate relationship between affiliate marketing and positive word of mouth; and affiliate marketing significantly affects positive word of mouth.

There is a positive and moderate relationship between web banner and customer retention; and web banner significantly affects customer retention.

There is a positive and moderate relationship between web banner and positive word of mouth; and web banner significantly affects positive word of mouth.

\section{Recommendations}

Having analyzed, discussed and interpreted the data collected in this study, the 
following recommendations are made;

1) Due to the competitive nature of the e-tailing firms, the advertising managers of e-tailing firms must develop and formulate e-mail marketing programs that will satisfy the needs of the consumers. Since other service providers have similar advertising messages, it is recommended that for a more distinguished and effective response from the customer, other forms of advert should be used.

2) Regular and consistent up-to-date training on product information should be given to the advertising agency so that they will have the current knowledge and skills to handle the adverts and also to ensure that product information is being emphasized so as to enlighten the customers.

3) As advert campaigns are relayed from different service providers, the web banners should be used to aid the customers to identify the company's products or service when they are making a purchase decision.

4) The company should also ensure that affiliate marketing agencies place their product adverts on stations and places where the consumers will easily identify with them and make a purchase. A good advert should be effective, persuasive and contain the necessary information on the products.

5) It is thereby recommended that e-tailing firms should get back to their intensive and aggressive advertising practice to keep their pace of growth.

6) Finally, it is suggested that market research and other studies be conducted to enable e-tailing firms identify those areas where promotional activities with effective advertising is lacking. They should also regularly examine the segments of the market that have been appealing so as to hold strongly on to them and to look for ways of attracting more customers.

\section{Contribution of the Study}

This study has contributed in the growing number of literature. Specifically, based on the findings from the study, the researcher proposes a heuristic model to show our contribution to knowledge.

From Figure 2 we observe that the relationship between E-mail Marketing and measures of Customer Satisfaction is very strong and is moderate on all other tested hypotheses implying that Online Advertising had a strong impact on Customer Satisfaction.

\section{Suggestions for Further Research}

The study was undertaken in the e-tailing firms which has a few firms. A further research should be undertaken to further explore the nature of online advertising in employing bigger samples and carrying out a more detailed analysis of firms. This would, in turn, help us get more insight into the nature of online advertising and informing various stakeholders on the benefits or otherwise of spending large sums of money on advertising. A study further needs to be undertaken to determine the medium that is mostly used by the e-tailing firms to 


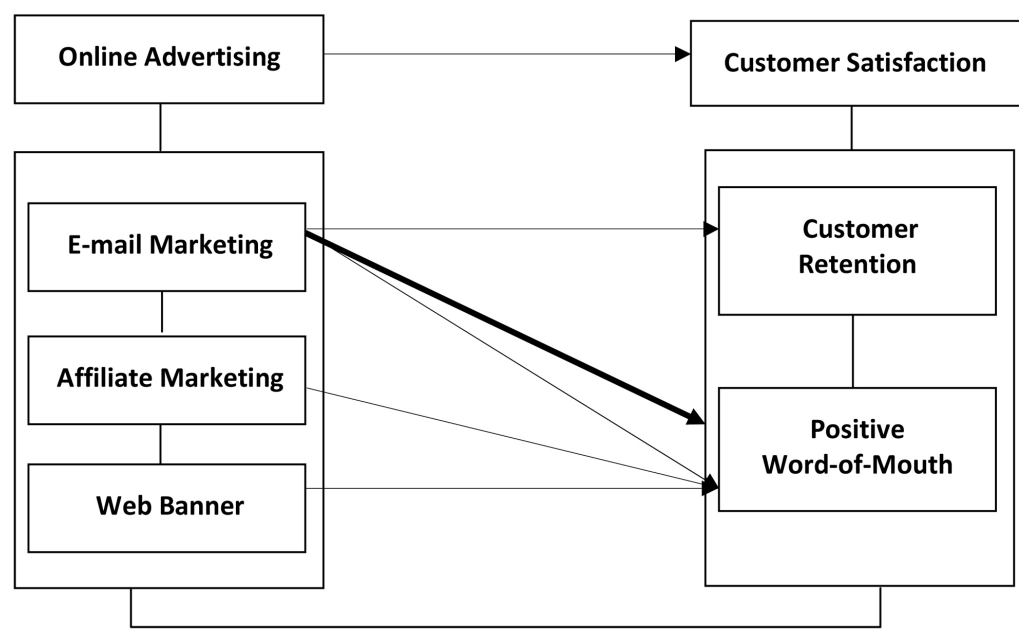

Figure 2. Heuristic operational framework of online advertising and customer satisfaction. Source: Researcher's new model. Key: — Very strong relationship; — Moderate relationship.

advertise their products.

\section{References}

[1] Halloway, L. (2004) Interference between Business and Customers. Research Paper, Turiba University, Riga.

[2] Zwass, V. (1996) Electronic Commerce: Structures and Issues. International Journal of Electronic Commerce, 1, 3-23. https://doi.org/10.1080/10864415.1996.11518273

[3] Ozuru, H.N. and Kalu, S.E. (2006) An Introduction to Electronic Marketing. Cutting Edge, Port Harcourt.

[4] Gabriel, J.M.O., Ogbuiwe, T.O. and Ahiauzu, L. (2016) Online Shopping Systems in Nigeria: Evolution, Trend and Prospects. Journal of Art and Social Sciences, 1, 1-7.

[5] Allard, C.R., Van, R. and Veronica, L. (2001) Exploring Consumer Evaluations of e-Services: A Portal Site. International Journal of Service Industry Management, 12, 359-377. https://doi.org/10.1108/09564230110405280

[6] Kotler, P. (2003) Marketing Management. 5th Edition, Pearson Education, Inc., London.

[7] Belch, G.E. and Belch, M.A. (1998) Advertising and Promotion: An Integrated Marketing Communications Perspective. 4th Edition, Boston McGraw-Hill, Boston.

[8] Akinkugbe, B. (2006) Fundamentals of Business Communication. Concept Publishing Inc., Lagos.

[9] Kotler, P. (2009) Marketing Management Analysis, Planning, Implementation and Control. Prentice Hall Inc., Upper Saddle River.

[10] Ashraf, B.M. and Mohammed, A. (2012) How Online Advertisements Do Affect Consumer Purchasing Intention: Empirical Evidence from a Developing Country. European Journal of Business and Management, 4, 2222-2239.

[11] Chaffey, D., Mayer, R., Johnston, K. and Ellis-Chadwick, F.E. (2003) Business-to-Business Internet Marketing: Strategy Implementation and Practice. Pearson Education-China Machine Press, Harlow.

[12] Tchai, T. (2011) Online Advertising Development and Their Economic Effective- 
ness. Australian Journal of Business and Management Research, 1, 121-133.

[13] Ramaraji, P. and Suzanna, A.W. (2003) Impact of Online Consumer Characteristics on Web-Based Banner Advertising Effectiveness. Global Journal of Flexible Systems Management, 4, 15-25.

[14] Ronald, E.G. and Barbara, A.L. (2002) Consumer Response to Web Sites and Their Influence on Advertising Effectiveness. Internet Research, 12, 318-328. https://doi.org/10.1108/10662240210438407

[15] Zheng, Z. and Yeqing, F. (2002) Users Attitudes toward Web Advertising: Effects of Internet Motivation and Internet Ability. Advanced in Consumer Research, 29, 71-78.

[16] Rodgers, S. and Chen, Q. (2002) Post-Adoption Attitudes to Advertising on the Internet. Journal of Advertising Research, 42, 95-104. https://doi.org/10.2501/JAR-42-5-95-104

[17] Philips Consulting (2016) Online Report: Study of Current Trends in Online Shopping in Nigeria. http://www.phillipsconsulting.net

[18] Philips Consulting (2014) Online Report: Study of Current Trends in Online Shopping in Nigeria. http://www.phillipsconsulting.net

[19] Raad, M., et al. (2010) Impact of Spam Advertisement through Email: A Study to Assess the Influence of the Anti Spam on the Email Marketing. African Journal of Business and Management, 4, 2362-2367.

[20] Stefan, S. (2011) Affiliate Marketing: A Case Study of Ticket Express Gesmbhochiket.com.

[21] Brown, B. (2009) The Complete Guide to Affiliate Marketing on the Web. Atlantic Publishing Group.

[22] Goodarz, J.D., Samin, R., Muhammad, S.R., Firoozeh, F., Neda Nahid, S. and Samaneh, F.J. (2012) A Conceptual Study on E-Marketing and Its Operation on Firm's Promotion and Understanding Customer's Response. International Journal of Business and Management, 7, 114-124.

[23] Rossiter, J.R. and Bellman, S. (1999) A Proposed Model for Explaining and Measuring Web Ad Effectiveness. Journal of Current Issues and Research in Advertising, 21, 13-32.

[24] Thomas, L. (2011) Online Marketing. McGraw-Hill, New York.

[25] Kaushik, A. (2010) Web Analytics. The Art of Online Accountability and Science of Customer Centricity. Wiley Publishing Inc., Indianapolis.

[26] Cho, C.H. (2003) Factors Influencing Clickers of Banner Ads on the WWW. CyberPsychology \& Behavior, 6, 201-215. https://doi.org/10.1089/109493103321640400

[27] Wirtz, J. (2003) Halo in Customer Satisfaction Measures. The Role of Purpose of Rating, Number of Attributes and Customer Involvement. International Journal of Service Industry Management, 14, 96-119. https://doi.org/10.1108/09564230310466001

[28] Carlsmith, J. and Aronson, E. (1963) Some Hedonic Consequences of the Confirmation and Disconfirmation of Expectations. Journal of Abnormal and Social Psychology, 66, 151-156. https://doi.org/10.1037/h0042692

[29] Baker, S.M. (2007) How Consumers with Disabilities Perceive Welcome in Retail Services Capes: A Critical Incident Study. Service Marketing, 21, 160-173. https://doi.org/10.1108/08876040710746525 
[30] Han, H.S. and Ryu, K. (2009) The Roles of Physical Environment, Price Perception and Sales Volume in Determining Profit Margin in the Family Restaurant Industry. Journal of Hospitality and Tourism Research, 33, 487-510. https://doi.org/10.1177/1096348009344212

[31] Gustafsson, A., Johnson, M.D. and Roos, I. (2005) The Effects of Customer Satisfaction: Relationship Commitment Dimensions, and Triggers on Customer Retention. American Marketing Association.

[32] Rosemond, B., Gloria, K.Q.A. and Eric, G. (2013) Factors Influencing the Retention of Customers of Ghana Commercial Bank within the Agonaswedru Municipality. International Journal of Marketing Studies, 5, 82-95.

[33] Ahasanul, H. and Ali, K. (2007) The Impact of Internet Marketing on Customer Satisfaction in Malaysia. International Journal of Marketing, 3, 1-18.

[34] Alan, S.A., Tarun, C. and Jason, K.D. (2010) A Multi-Industry, Longitudinal Analysis of the Email Marketing Habits of the Largest United States Franchise. Journal of Direct, Data and Digital Marketing Practice, No. 11, 187-189.

[35] Al-Fadhli, S. (2011) Critical Success Factors Influencing e-Commerce in Kuwait. Journal of Internet Banking and Commerce, 16, 1-7.

[36] Alghamdi, R., Drew, S. and Alhussain, T. (2012) A Conceptual Framework for the Promotion of Trusted Online Retailing Environment in Saudi Arabia. International Journal of Business and Management, 7, 140-149. https://doi.org/10.5539/ijbm.v7n5p140

[37] Aminu, S.A. (2011) The Relevance of E-Marketing in Achieving Competitive Advantage in the Nigerian Banking Sector. Lagos Journal of Entrepreneurship and Technology, 1, 125-136.

[38] Anunobi, C.V. and Mbagwu, F.C. (2009) Determinants of Internet Use in Imo State, Nigeria. Educational Research and Review, 4, 436-442.

[39] Alomaim, N., Zihni, M. and Zairi, T.M. (2003) Customer Satisfaction and Shareholder Value. Journal of Marketing, 68, 172-185.

[40] Birkner (2012) The ABC's of Affiliate Marketing. Marketing News.

[41] Asikhia, O. (2011) E-Banking Patronage in Nigeria: An Exploratory Study of Gender Difference. Business Intelligence Journal, 4, 243-252.

[42] Auta, E.M. (2010) E-Banking in Developing Economy: Empirical Evidence from Nigeria. Journal of Applied Quantitative Methods, 5, 212-222.

[43] Business Marketing Plan (2011) The Advantages and Disadvantages of E-Mail Marketing. http://www.businessmarketing.com

[44] Chong, A.Y.L., Keng-Boon, O., Lin, B. and Shu Yi, T. (2009) Influence of Inter Organizational Relationships on Smes' E-Business Adoption. Internet Research, 19, 313-331. https://doi.org/10.1108/10662240910965379

[45] Chuttur, M.Y. (2009) Overview of the Technology Acceptance Model: Origins, Development and Future Directions, USA, Indians University. Sprouts: Working Papers on Information System, Vol. 9.

[46] Duncan, M. (2011) Theory and Audience Analysis. Elon University, Elon.

[47] Faribori, E. and Zahedifard, M. (2012) Email Marketing: Advantaged, Disadvantages and Improving Techniques. Journal of E-Education, E-Management, 2, 233-236.

[48] Olusoji, J.G., Ogunkoya, O.A., Lasis, J.O. and Elumah, L.O. (2015) Risk and Trust in Online Shopping: Experience from Nigeria. International Journal of African and Asian Studies, 11, 71-77. 
[49] Oudan, R. (2010) Strategic Decision-Making in the Emerging Field of E-Commerce. International Journal of Management and Information System, 14, 12-15.

[50] Owen, E.R. (2017) Small Business.com. Hearst Newspapers.

[51] Quan, S., Hao, C. and Jianxin, Y. (2010) Factors Influencing the Adoption of Mobile Service in China: An Integration of TAM. Journal of Computers, 5, 799-806.

[52] Peter, D.N., Muhammad, N. and Andrew, M. (2013) Relationship Marketing, Word of Mouth Communication and Consumer Loyalty in the Ugandan Mobile Telecommunication Industry. African Journal of Business Management, 7, 354-359.

[53] Techcity (2015).

http://www.techcityng.com/65-of-internet-users-in-nigeria-already-shop-online-pa ypal

[54] Schultz, R.J., Schwepker Jr, C.H. and Good, D.J. (2012) Social Media Usage: An Investigation of B2B Salespeople. American Journal of Business, 27, 174-194. https://doi.org/10.1108/19355181211274460

[55] Venu, G.K. and Santosh, R.N. (2012) Search Engine Optimization-A Tool for Advertising in India. The International Journal, 1, 1555-2251. 